\title{
〔一般講演〕
}

\section{(15) オンライン灰分計の混炭プロセス制御への適用について}

(財) 石炭技術研究所 小野寺 次 郎

\section{1. 緒言}

石炭利用拡大に伴い, 品質に対する要求がさらに強まるすのと 予測されるので，原炭等の性状をでをるだけ早期に把握して，そ の情報により選炭工程を最適化するととが必要と交ろう。当所 では, 選炭自動化試験の一環として, 放射性同位元素 ${ }^{241} \mathrm{Am}$ 及び ${ }^{137} \mathrm{Cs}$ 在用的る 2 線源透過式の灰分計在開発し, オンラインで重 液サイクロン (麻生吉櫭炭鉱 $)^{2)}$, 空気道シク (三菱大夕張炭鉱 $)^{3)}$, およぴ混炭プロセス（三井三池炭鉣）社）芯用し，多種の成果を 収めたが，試験実施当時の電算機は真空管式あるいはトランジス 夕式で故障が多く，定灰分計本体が振動飞弱り等のハードウェ ア上の問題点があり,さらに灰分 $15 \%$ 以下の低灰分炭については 誤差が大きかつた。

近年電算機技術が高度に発達し, 当時困難であつた各種の問題 点を克服しらる見通しが得られたので, 再び本方式を採用し, 三 菱高島炭鉱における精炭, 2 号炭の混炭プロセス制御に適用すへ く, 石炭技術振興補助金の交付老受けて, 昨年度末に石炭灰分計 2 式を含を設備を設置した。以下沉その概要走報告する5)。

\section{2. 試験装置および方法}

\section{$2 \cdot 1$ 石炭灰分計}

放射性同位元素, ${ }^{241} \mathrm{Am}, 300 \mathrm{mC}$ i および ${ }^{137} \mathrm{Cs}, 100 \mathrm{mCi}$ の ガンマ線を石炭仅照射し，それぞれの透過強度をシンチレーショ ン計数管で連続的に検出し, 予め作成した回帰式により, 各計数 率を基飞灰分值を信号処理器で演算し, 計測装置にディシタル表 示するとともに，外部にアナログで出力する力式である(メーカ は富士電機製造)。

(1) Cフレーム: 線源容器と検出器がベルトコンベヤ上の石炭 を摤んで装着され, 他飞警報表示灯, 冷却水管, 清掃用空気管が 付設されている。本体は軌道上に設置され，校正時にはペルトコ
ンベヤから退避でをる。 ${ }^{241} \mathrm{Am}$ 用と ${ }^{137} \mathrm{Cs}$ 用の 2 台のCフレーム が約 $1 \mathrm{~m}$ 離れて配置され，1対老構成する(第1，2図）。

(2) 計測装置および信号処理器：計測装置は，イ）検出器と信 号処理器のインターフェース, 口) 検出器電源の供給, ハ) Am 線 源容器のシャッタ開閉, 二) 計数時間および遅れ時間の設定, ホ) 各計数值沶よび死分值の表示, 一) 灰分信号の 4 20 m ADC出

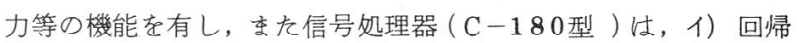
式に上る灰分の演算，口）各種制御モードの選択，八) 結果の印 字処理等, 電算機の機能を最大限飞発揮する。

（3）灰分測定原理：Amおよび $\mathrm{As}$ 線源からのガンマ線の基準強 度（ベルト上石炭なし）をそれぞれ $F_{10} ， F_{20}$ ，透過強度をそれぞ れ $F_{1}, F_{2}$, 質量吸收係数を $\mu_{1}, \mu_{2}$, 力密度 $\rho$, 石炭層厚を しとすれば，つぎの式が成立する，

$$
\begin{aligned}
& F_{1} / F_{10}=B_{1} * \operatorname{eXp}\left(-\mu_{1} \rho \ell\right) \\
& F_{2} / F_{20}=B_{2} * \operatorname{eXp}\left(-\mu_{2} \rho \ell\right) \ldots \ldots \ldots \ldots \ldots \ldots \ldots \ldots \ldots \ldots \ldots \ldots \ldots \ldots \ldots \ldots \ldots \ldots \ldots \ldots \ldots \ldots \ldots
\end{aligned}
$$

ここに, $B_{1}$ と $B_{2}$ 壮再生率である。Cs ガンマ線のエネルギーが

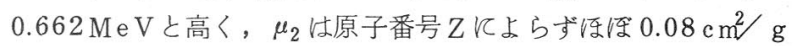
なのに対し, Amガンマ線のそれは最高 $0.06 \mathrm{MeV}$ と低く， $\mu_{1}$ は $\mathrm{Z}$ ととも增加する傾向飞ある。可燃分（ C, H， O等）子不燃 分 $\left(\mathrm{Si}, \mathrm{Al}, \mathrm{Fe}\right.$ 等) の $\mu$ 在それぞれ $\mu_{\mathrm{c}}$ 就び $\mu_{\mathrm{a}}$, 灰分在 $\mathrm{A}$ \%とす机ば， $\mu$ 壮加成性が成立するから，

$$
\begin{aligned}
\mu_{1} & =\mu_{\mathrm{c}} *(100-A) / 100+\mu_{\mathrm{a}} * A / 100 \\
& =A *\left(\mu_{\mathrm{a}}-\mu_{\mathrm{c}}\right) / 100+\mu_{\mathrm{c}} \ldots \ldots \ldots \ldots \ldots \ldots \ldots \ldots
\end{aligned}
$$

再生率 $B$ が 1 なら, 第 1,2 式は,

$$
\begin{aligned}
& P_{1}=\ln \left(F_{1} / F_{10}\right)=-\mu_{1} \rho \ell \\
& P_{2}=\ln \left(F_{2} / F_{20}\right)=-\mu_{2} \rho \ell
\end{aligned}
$$

$\rho \ell$ 消去し, さらに

$$
P=\mu_{1} / \mu_{2}
$$

また，第 $3 ， 4$ 式の $\mu_{\mathrm{a}}, \mu_{\mathrm{c}}, \mu_{2}$ 专新しい定数 $\alpha, \beta$ 江含めてA につけて解けば,

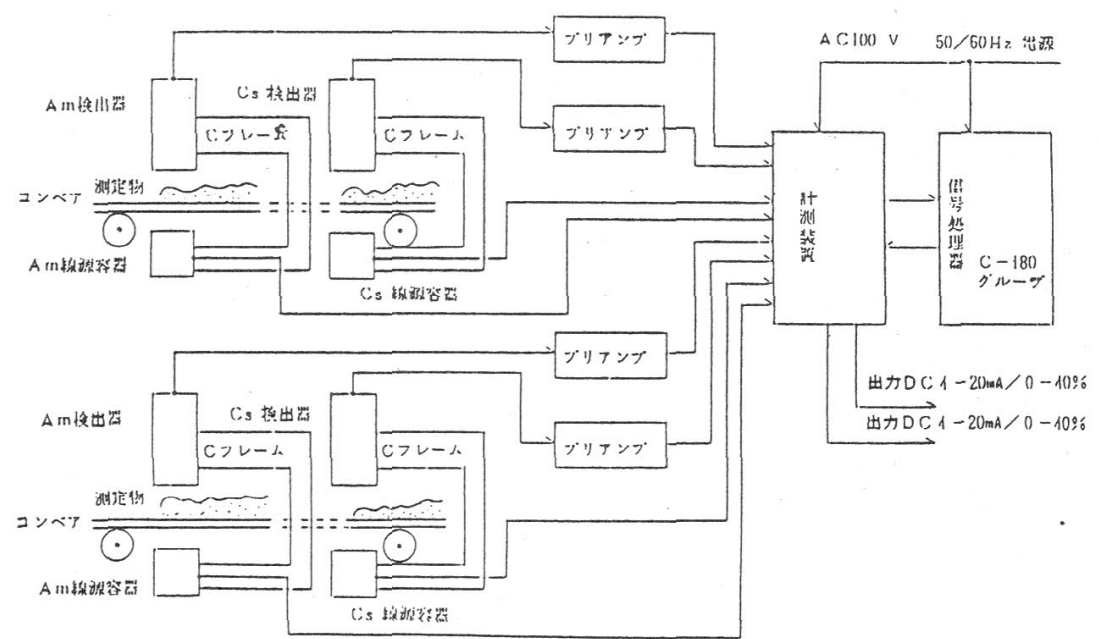

第1図 石炭灰分計ブロックダイヤグラム



第2図Cフレーム

$810<38>$ 


$$
A=\alpha P+\beta
$$

すなわち, 変数 $P$ と灰分 $A$ の間には直線関係が存在し, 灰分既知 の石炭に関する実験により回帰式が算出され，未知試料の測定に より得た $P$ を用いて，灰分值 $A$ が推定される。

\section{$2 \cdot 2$ 精炭, 2 号炭払出儿装置}

本装置は, 調節計 $(2$ 台 $)$, 絶縁信号変換器その他より構成さ れ，灰分計，コンベヤスケールならびにレベル計の信号を受信し 目標の一般炭灰分および払出量 $(\mathrm{t} / \mathrm{h})$ を達成すべく精炭および 2 号炭の払出量を演算し, 制御信号を各供給装置 (振動フィーダ) 反出力する方式である(第 3 図参照)。

(1) 調節計 ( P M K 型コンパクトコントローラ) : ウェ八登録 式のプログラムイより, 各種の制御を行なら。

（2）精炭灰分設定器（PMM型コンパクトガリキュレータ）: 精炭灰分計が未設置なので，代用として設置した。

\section{$2 \cdot 3$ 精炭, 2 号炭払出量の設定}

2 号炭, 精炭および混炭後の一般炭の払出量 $(\mathrm{t} / \mathrm{h})$ 和よび死 分をそれぞれ $W_{1}, A_{1}, W_{2}, A_{2}$ および $W_{3}, A_{3}$ とすれば，物質収 支等により，つぎの各式が成立する，

$$
\begin{aligned}
& W_{3}=W_{1}+W_{2} \\
& W_{3} * A_{3}=W_{1} * A_{1}+W_{2} * A_{2} \\
& A_{1} \geqq A_{3} \geqq A_{2}
\end{aligned}
$$

一般炭の目標払出量 $\bar{W}_{3}$ および灰分 $\bar{A}_{3}$ が与えられれば， 2 号炭お よざ精炭の払出比率すなわち混炭比率 $k$ および $(1-k)$ が, つ ぎのように算出される。すなわち，

$$
k=\frac{\bar{A}_{3}-A_{2}}{A_{1}-A_{2}},(1-k)=\frac{A_{1}-\bar{A}_{3}}{A_{1}-A_{2}} \cdots \cdots
$$

したがつて，2号炭および精炭の目標払出量は，乙れらに $\bar{W}_{3}$ を 乗算したものとなる。

\section{3. 結果および考察}

設備の設置から日が浅く，目下灰分計の調整中であるが，乙れ までに得られた結果ならびに予想される問題点について記す。

\section{$3 \cdot 1$ 石炭灰分計の調整}

高島選炭工場の精炭をはじめ各種産物を使用し, 約 $180 \mathrm{~mm} の$

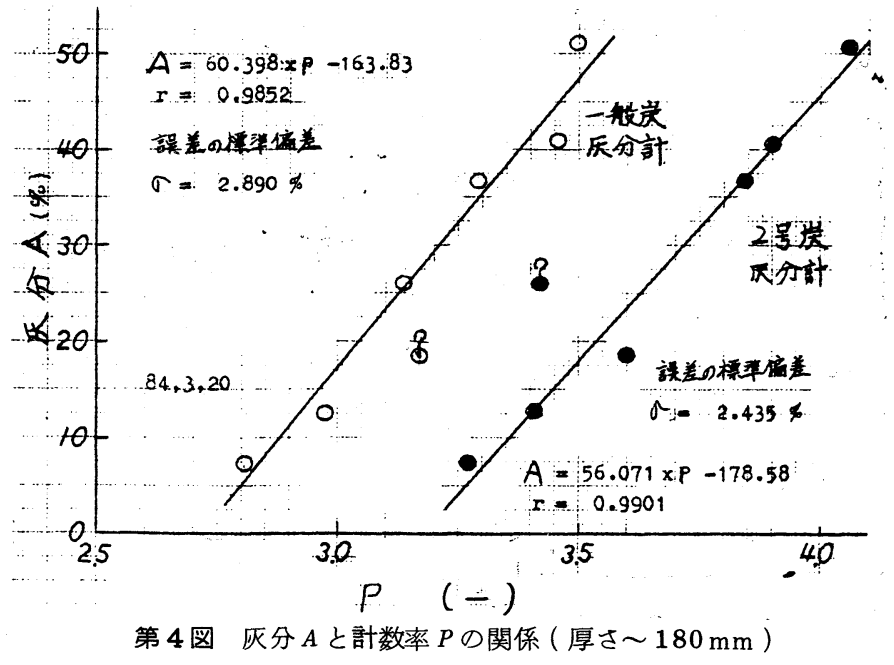

厚さとしてカンマ線計数率測定を行なつた。第 4 図に示すように， 灰分 $A$ が 7 50\%の範囲で, 異常值と思しきデータを除外して推 定誤差 $\sigma$ が $2.5 \sim 3 \%$ となり, 間関係数もほぼ 0.98 亿達した。

つぎに，厚さを $60 \sim 150 \mathrm{~mm}$ 亿段階的に変えて計数率測定を 乾試料について試みた。第 5 図に示すように, 第 1,2 式の対数 変換が直線関係になく, 再生率 $B$ を考慮せざるを得ないことが判 明した。同図 $(\mathrm{b})$ 亿示すよ 5 亿, 灰分 $A$ と変数 $P, P_{2}$ との間には, つぎの重相関々係が成立するよらに見らけられる。

$$
A=\alpha * P+\beta+P_{2}+\gamma
$$

8 試料，4段階の厚さについて得られた重回帰分析結果は, 同図 (c)の中に記すように, 推定誤差が約 $5 \%$ と大りるのの, 重相 関係数 $R$ が約 0.95 とかなり高く, 第 10 式の信頼性が高いてとが わかる。同図 (c) の示すとてろでは, 石炭層をある程度厚くして 一定に保てば，推定誤差が減少するととが期待できる。

3・2 R I 灰分計における問題点

（1）再生率：再生率 $B$ Kは, 散乱ガンマ線と蛍光X線の 2 種類 が考えられ, 前者は灰分計の幾何学的条件と石炭厚さ $(\rho \ell)$ によ り，また後者は灰の組成等により定まる。したがつて，Bの影響 を軽減するためには，1）ガンマ線束を絞る，口）金属板等によ

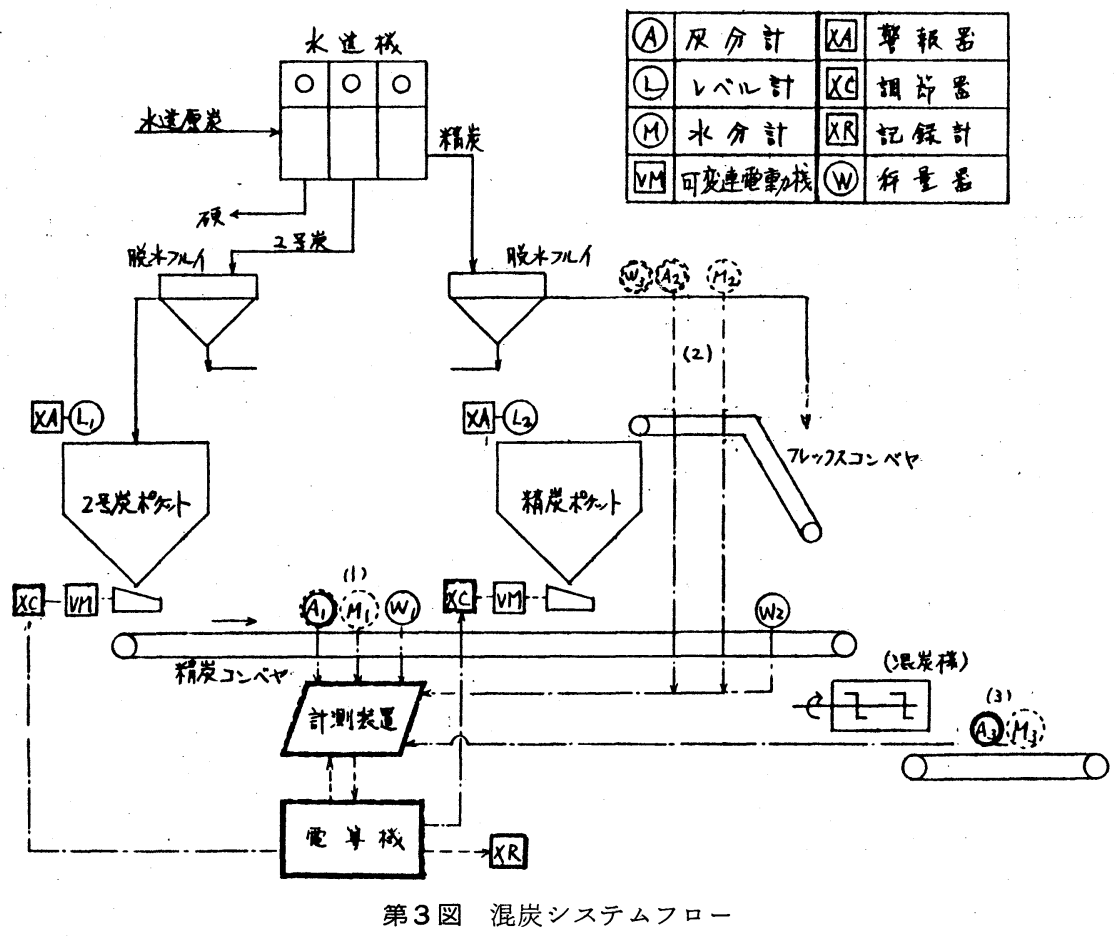

り蛍光X線の計数を除する, といつた対策 が考えられる。

(2) 灰の組成の影響： $\mu_{2}$ は Zとともに 増加する傾向があるため, 灰中の $\mathrm{TiO}_{2}$, $\mathrm{Fe}_{2} \mathrm{O}_{3}$ 含有率が高い場合は注意を要する。 （3）湿分の効果：湿分が高い場合，指示 灰分值は相対的に低下する管であるが， $\mathrm{Am}$ ガンマ線のHに対する $\mu$ はCのそれよ りる大きく，したがつて，湿分または石炭 中の $\mathrm{H} / \mathrm{C}$ 元素比が高いとさは，指示灰分 值が逆に高くなるととも予想され，将来は 水分計による補正を要する事態も考えられ る。

（4）粒度の影響：石炭中の微粉割合が高 いとをは,ガンマ線の散乱が大なくなり， とくにAmカンマ線が強く散乱されるとと が推察され, 指示灰分值の変動が懸念され る。
4. 結
言

本灰分計の適用により，1）原炭をはじ め各産物の灰分值のオンライン測定が可能 

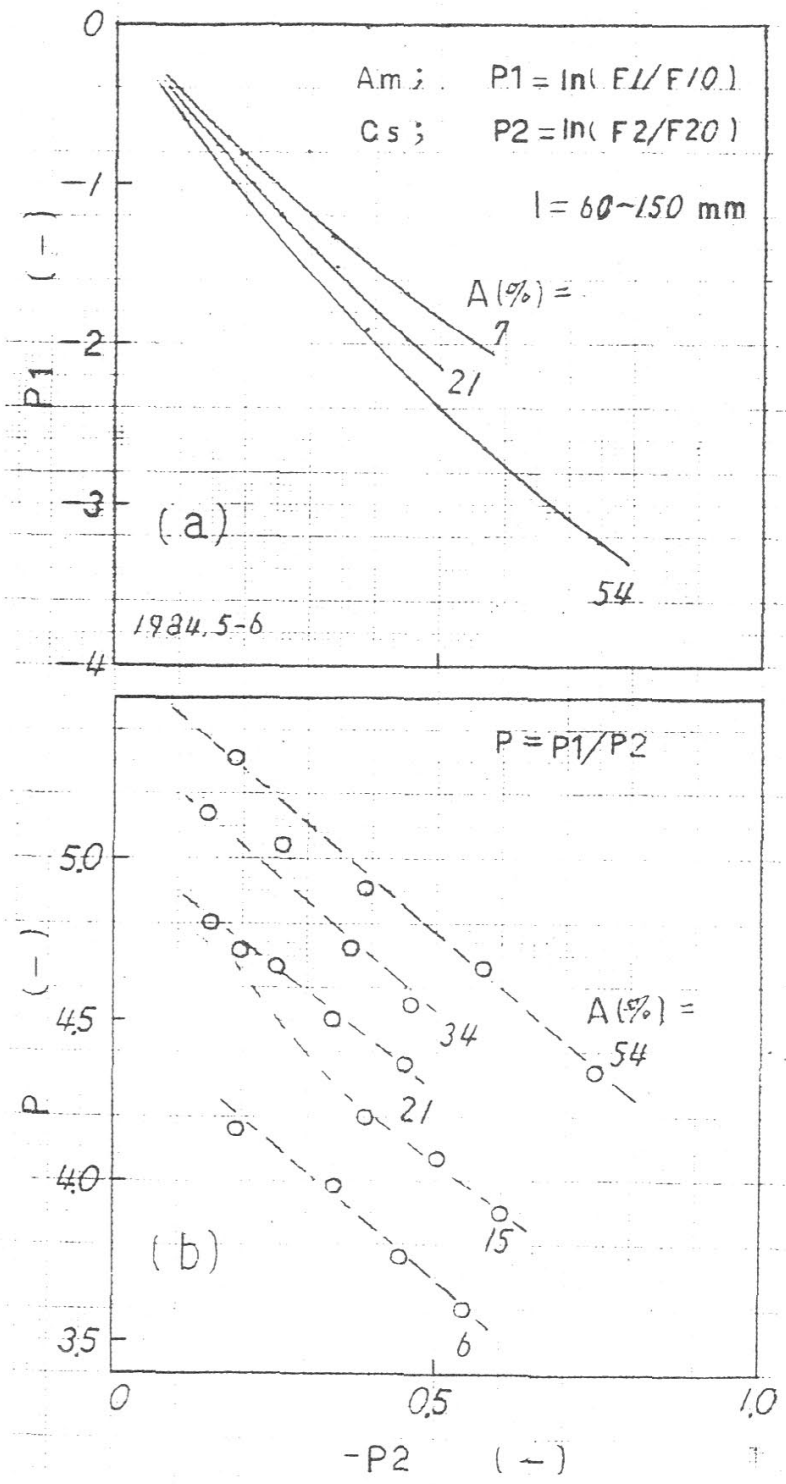

となり，2)精宸，2号炭の払出量制御化よつて一般炭混炭産物 の品質向上と安定化加図られ, 所定の品位を保証でき，3）歩留

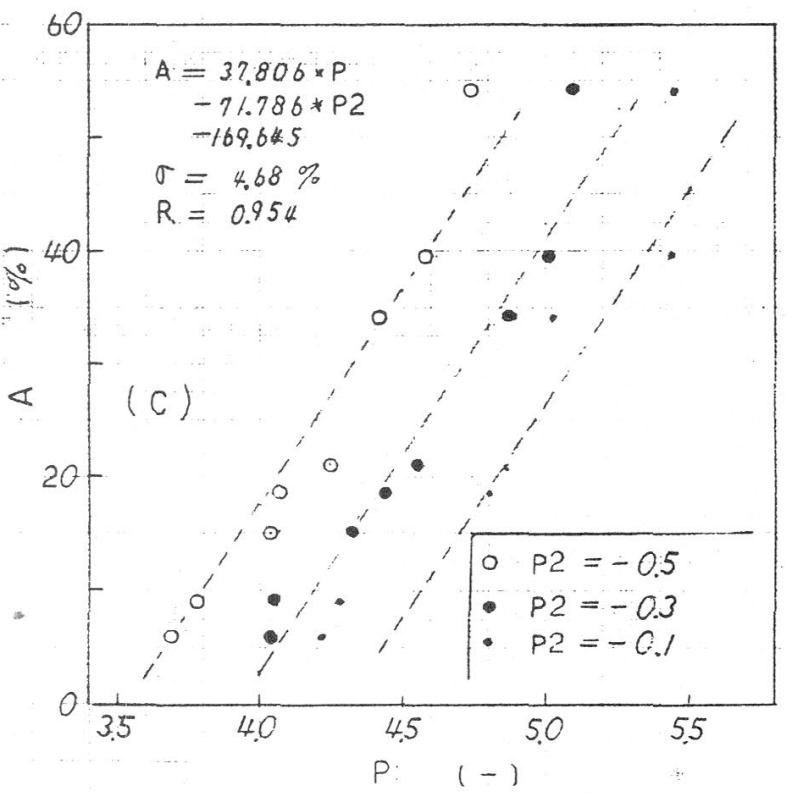

第 5 图 (a)〜(c)厚さを变えた場合の試験結果

りが向上し, 山元手取りの増加が期待でをるともに，4）水選 機操業の高度制御あるいはコールセンタ等の石炭利用分野への波 及効果子予測され，石炭利用拡大の一助をりらるものと推察され る。

文献

1) 鎌田他：第 6 回石炭利用技術研究発表会講演集, 石炭技術研 究所 (昭和 59 年 8 月 ) , p. 105 111

2) 石炭技術研究所報告書第 56 号, 選炭自動化試験, 重液サイク ロンによる自動化試験, 昭和 43 年 11 月

3)「空気動ジグの自動化試験」: 石炭技研, Vol。11, No. 1, ( Jan. 1971)

4)「混岑の自動化試験 」: 石炭技研, Vol. 9, No. 11, (Nov.1970)

5）昭和 58 年度石炭技術振興補助事業成果報告書, 精炭品質安 定化等のをめの装置開発, システム化㳊関する研究一B, 混 炭プロセスの開発, (昭和 59 年 4 月)
大分 鉱業史話. (2)

国東半島の目の前に姫島が浮かんでいる。 瀨戸内にある島の中でも特に行つてみたい 島のひとつであつたが，このほど日本鉱業 史研究会の現地研究会に際して思い切つて 足をのばして同島に渡つてみた。昔塩田の 島であつたというが，島の資料館に意外な 展示品を見付けて驚かされた。島には幕末 幕府の石炎貯蔵所があり, それが火災に遭 つた折の石炭の然えがラであると説明され
ている。考兄てみれば, 幕末外国から蒸気 船を購入，その然料は必要欠くべからざる もので，しかるべき留䝪蔵所がないと当 時の船は動くことがでさ疗からた。したが つて, 航海上拠点となる場所には眝炭する 必要があつたわけである。最近, 小野田市 では石炭の燃えガラの山を文化財に指定し た由であるが，生産に関連する遺跡として， 今後保存して行く上には，まことに大切な ことであろう。姫島の石炭ガラも, どこの 産地によるものか, その品質はなど調べる のに重要な手懸りを与えてくれるものであ る。

（葉賀七三男）

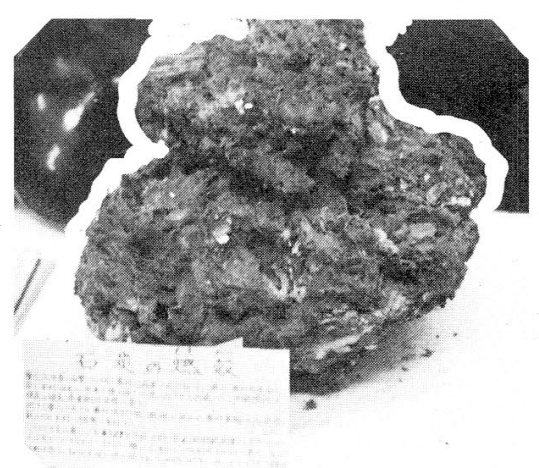

石炭燃えがら ( 姫島村資料館所藏) 